\section{"Expedition Nails"}

SIR,-Among the hazards of going to wild places is that of protein deficiency. Optimistically, travellers rely on being able to buy adequate food locally, and sometimes this optimism turns out to be groundless. Last autumn I was a member of an expedition to the remote highlands of Tigre in Ethiopia, and for six weeks we existed largely on local bread (hambasha), eggs, and very little meat (one hen for all during four weeks). Stupidly, for financial reasons, we had not taken adequate tinned meat. In the course of a month nine out of 10 members of the expedition, including one Ethiopian, walked an average of 600 miles $(965 \mathrm{~km})$ in very rugged terrain. On our return (2 October 1974) several of us were weak and exhausted. In one 52-year-old male the total serum protein and albumin levels were normal (77 and $44 \mathrm{~g} / 1$ (7.7 and $4.4 \mathrm{~g} / 100$ $\mathrm{ml})$ ) but the blood urea was slightly elevated $(8.6 \mathrm{mmol} / 1(52 \mathrm{mg} / 100 \mathrm{ml}))$. On 10 February 1975 the figures were: total protein $75 \mathrm{~g} / 1(7.5 \mathrm{~g} / 100 \mathrm{ml})$, albumin $43 \mathrm{~g} / 1$ $(4.3 \mathrm{~g} / 100 \mathrm{ml})$, creatinine $127 \mu \mathrm{mol} / 1(1.44$ $\mathrm{mg} / 100 \mathrm{ml}$ ), urea $6.64 \mathrm{mmol} / \mathrm{l}(40 \mathrm{mg} / 100$ $\mathrm{ml})$. On neither occasion were the transaminase levels elevated. That and loss of weight $(1-2$ stones $(6-12 \mathrm{~kg}))$ in all members suggested that we had been breaking down our own muscle. In all members of the party except the cook, the only person who did not walk long distances and who lost weight, a white band appeared on all the nails corresponding in width roughly to the period of semistarvation.

I have seen the same typical sign in other members of Oxford expeditions who have been referred to me by their college doctors with gastrointestinal upsets for which no obvious cause could be found other than a protein-deficient diet and inadequate calorie intake in the face of severe exercise. In none were the plasma proteins abnormal. These changes in the nails are very similar to those described by Muehrcke ${ }^{1}$ in hypoproteinaemic states.-I am, etc.,

Radcliffe Infirmary,

B. E. JUEL-JENSEN Oxford 1 Muehrcke, R. C., British Medical fournal, 1956,

\section{Myeloid Leukaemia and Cot Deaths}

SIR,-It was suggested by Dr. Alice $M$. Stewart (18 November 1972, p. 423) that myeloid leukaemia might be a numerically important cause of cot deaths. In some 120 cases of sudden death in infancy in which detailed necropsies were carried out between 1970 and 1973 no evidence of leukaemia was seen. However, in view of the interesting statistical facts put forward by Dr. Stewart and bearing in mind that it is possible that acute leukaemias may go unrecognized at necropsy, 30 cases of cot death during 1973 and 1974 were subjected to a particularly careful haematological examination of the blood and bone marrow.

No evidence of leukaemia was seen in any of these cases, the only variation from the normal pattern being an excess of plasma cells in the marrow in some infants who had minor degrees of infection in the respiratory tract. The significance of the latter is uncertain, but it would appear from our find- ings that myeloid leukaemia is not a significant cause of cot death.-We are, etc.,

\section{E. TAPP}

Department of Pathology,

B. W. OTRIDGE

Withington Hospital, Manchester

\section{Gentamicin and Gas Gangrene}

SIR,-Mr. R. H. Livingstone and Mr. R. I. Wilson report the use of gentamicin for the treatment of gas gangrene in their paper "Gunshot Wounds of the Limbs" (22 March, p. 667). Since clostridia are resistant to the aminoglycoside group of drugs, little therapeutic benefit could be expected from the use of gentamicin in clostridial myositis.

Though antibiotic drugs play only a subsidiary role in the treatment of gas gangrene, the drug of first choice is penicillin and the second erythromycin. The most important single factor in treatment is to attempt to produce, by the removal of foreign bodies and dead tissue and the use of hyperbaric oxygen, an environment in which anaerobic bacteria are unable to multiply.

A type of myositis clinically resembling gas gangrene may follow infection by anaerobic streptococci, often in association with enterobacteria. Gentamicin may be required in this condition if the enterobacteria are resistant to the more commonly used, less toxic drugs. - I am, etc.,

Public Health Laboratory,

J. A. RyCRofT $\begin{aligned} & \text { City Hospital, } \\ & \text { Nottingham }\end{aligned}$

"Doctor in the Army"

SIR,-I read Dr. K. H. Hedges's letter (8 February, p. 333) on the misleading nature of the R.A.M.C. advertising literature and administrators' advice with interest. It is even more interesting when one compares the relative obscurity of the truth with the double-page advertisement of promises that government money can buy.

At one time the B.M.A. refused to advertise any service posts and personally I feel this should be done again on two counts: (a) the generally misleading nature of the advertising and $(b)$ the fact that the Government has two standards of medical pay not equated to the level of responsibility or the amount of work performed. I refer, of course, to the service junior staff/N.H.S. comparison.-I am, etc.,

B. H. VAlentine Public Helmsfor

\section{Treatment of Bowel Wounds}

SIR,-In their excellent review of "Gunshot Wounds of the Trunk" (29 March, p. 728) Mr. H. M. Stevenson and Mr. W. Wilson recommend the use of primary anastomosis after resection with, on occasion, an added proximal decompression in injuries of the large bowel. By their own admission the intraperitoneal sepsis rate was extremely high and a number of patients developed faecal fistulae. The technique stands condemned by these complications. Since the first world war successive generations of battle surgeons have had to learn the bitter lesson that exteriorization of colon wounds with or without resection of damaged bowel is the only safe method. For a while in Vietnam it seemed as though an exception could be made for the right colon, but sepsis and suture-line complications quickly led to a reversion to resection with terminal ileostomy and a mucous fistula. As $\mathrm{Mr}$. Stevenson and $\mathrm{Mr}$. Wilson so rightly point out, if the wounded survive to reach hospital the main causes of death are now sepsis and the organ failure that ensues. Thus every effort should be made to keep dangerous sepsis in body cavities to a minimum.

Finally, they comment on the speed with which in Belfast the casualties reach hospital and say that in other campaign conditions longer delays will be likely and thus the surgical problems posed will solve themselves by death along the evacuation path. It is true that each war is unique and, as a recent publication shows, prediction is extremely difficult. ${ }^{1}$ Nevertheless, it would be a failure to recognize the skill and self-sacrifice of

\section{Possible Role of Laxatives in Analgesic} Nephropathy

SIR,-Recently Drs. T. S. Wainscoat and R. Finn (21 December, p. 69) proposed the hypothesis that the regular use of laxatives might be an important contributory factor in the pathogenesis of analgesic nephropathy. However, the analysis of their data and our own findings raise some objections against this interesting idea.

(1) Two of their 10 patients who were supposed to have analgesic nephropathy had used aspirin alone. In the remaining eight cases the estimated amount of ingested phenacetin is not exactly indicated ("at least $5 \mathrm{~kg}$ of aspirin or phenacetin"). This information, however, seeems to be essential, since observations from all over the world strongly suggest that phenacetin is the most important (if not the only) causative factor in analgesic nephropathy. In contrast, the evidence that aspirin alone may cause analgesic nepropathy in man is far from being convincing. ${ }^{1}$

(2) Our observations in 150 cases with established phenacetin nephropathy differ in the following points from Drs. Wainscoat and Finn's findings (their figures in parentheses): female:male ratio, 104:46 (4:6); mean plasma potassium concentration, $4.45(3.38) \mathrm{mmol}(\mathrm{mEq}) / 1$; cases with plasma potassium concentration of 3.5 $\mathrm{mmol} / \mathrm{l}$ or less, $9.3 \%(70 \%)$; laxative abusers, $3.3 \%(80 \%)$. In 21 additional patients with a similar degree of phenacetin abuse but without nephropathy we found $14.4 \%$ laxative abusers.

(3) Drs. Wainscoat and Finn compared the plasma oreatinine levels in two subgroups of patients with rheumatoid arthritis 